\title{
СТАН СПЕЦИФІЧНОГО ІМУНІТЕТУ ДО ЕНДОТОКСИНУ У ХВОРИХ НА БРОНХІАЛЬНУ АСТМУ З ФІКСОВАНОЮ/ЗВОРОТНОЮ ОБСТРУКЦІЕЮ
}

\author{
Національний медичний університет ім. О.О. Богомольця, м. Київ
}

\begin{abstract}
У дослідження було включено 331 хворого на бронхіальну астму. Залежно від ступеня пост-бронхо-

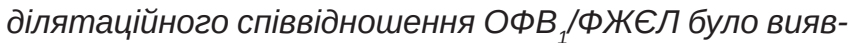
лено 151 пацієнта з фріксованою та 180 зі зворотною обструкцією. Рівні антиендотоксинових антитіл класів A, M, G та sCD14 визначали методом твердофразного імуноферментного аналізу. Результати дослідження показали, що вміст антиендотоксинових антитіл класу G був вище $(p<0,001)$ контролю в обох групах, при цьому рівень цього імуноглобуліну був вище $(p<0,05)$ у пацієнтів з фріксованою обструкцією. Концентрація SCD14 в індукованому мокротинні була вище $(p<0,001)$ контролю в обох досліджуваних групах, хоча вміст цього медіатору в сироватці був вище $(p<0,05)$ контролю тільки в пацієнтів зі зворотною обструкцією.
\end{abstract}

Ключові слова: бронхіальна астма, ендотоксин, імунітет.

Клінічні симптоми бронхіальної астми (БА), як правило, пов'язані з обструкцією бронхів, яка може бути зворотна спонтанно або після призначення адекватної терапії [1]. У частини хворих на бронхіальну астму обструкція бронхів може бути незворотною незважаючи на оптимальну фрармакотерапію. Дані про частоту такого френотипу астми досить сильно різняться і в середньому становлять від 20 до 50 \% від усіх хворих [2].

Фіксована обструкція на відміну від зворотної може бути асоційована з більш вираженим патологічним ремоделюванням бронхіальної стінки під дією різних запальних медіаторів, у тому числі тих, що виділяють еозинофріли, нейтрофріли та інші імунокомпетентні клітини [3]. Відомо, що ендотоксин грамнегативних бактерій $є$ сильним стимулятором даних клітин, що в кінцевому результаті призводить до гіперпродукції прозапальних цитокінів, які підсилюють ремоделювання бронхів [4].

Ендотоксин (ЕТ), або ліпополісахарид (ЛПС), є головним компонентом зовнішньої мембрани грамне- гативних бактерій. Наприклад, бактерійна стінка E. coli має приблизно $10^{6}$ молекул ЛПС [5]. ЛПС складається 3 трьох компонентів: полісахаридний ланцюг (О-антиген), сердечник (core) і ліпід A, який закріплює молекулу лПС у зовнішній мембрані грамнегативних бактерій. Найбільша мінливість спостерігається в складі і кількості залишків цукру, що утворюють О-антиген. Більше 60 видів залишків цукру і 30 нецукрових елементів $€$ компонентами О-антигену. До основних моносахаридів О-антигену відносять глюкозу, фрруктозу, галактозу, манозу і рамнозу [6]. Розпізнавання ЛПС є багатоступінчастим процесом, що вимагає співпраці ряду білків, таких як ЛПС-зв'язувальний білок (ЛЗБ), CD14 рецептор і TLR4/ MD-2 комплекс [7].

Мета роботи: вивчити стан антиендотоксинового імунітету у хворих з частими та нечастими загостреннями бронхіальної астми.

\section{Пацієнти і методи}

У дослідження було включено 331 хворий на БА. Діагноз і лікування бронхіальної астми проводилися відповідно до критеріїв чинного наказу МОЗ України № 128 від 19.03.2007 p.

Ступінь обструкції визначали за ступенем постбронходілятаційного співвідношення ОФВ $/$ /ФЖЄЛ. Для фріксованої обструкції співвідношення ОФВ $/$ /ФЖЄЛ становило $<0,7$ (70\%), а для зворотної > 0,7 (70 \%) [2]

Рівні антиендотоксинових антитіл класів А, M, G (відповідно анти-ET-IgA, анти-ET-IgM і анти-ET-IgG) визначали методом твердофразного імуноферментного аналізу (ІФА), виражали в умовних одиницях оптичної щільності кінцевого продукту фрерментативної реакції [8].

Секреторний антиендотоксиновий імуноглобулін А (анти-ET-slgA) в індукованому мокротинні визначали методом твердофазного ІФА за протоколами, розробленими в лабораторії клінічної імунології ЦНДЛ ДУ «Кримський державний медичний університет ім. С.І. Георгієвського» [9].

Рівень SCD14 у сироватці та індукованому мокротинні визначали методом твердофразного ІФА з використанням 
тест-системи «Hbt Human sCD14 ELISA Kit, Product Number: HК320» виробництва «Hycult biotechnology» (Голландія). Оптичну щільність визначали на аналізаторі «StatFax 2100» на довжині хвилі 450 нм. Зміст SCD14 у сироватці виражали в мкг/мл, в індукованому мокротинні - в нг/мл.

Групу контролю склали 92 практично здорові осіби. Всі волонтери досліджувалися на предмет алергічної патології за допомогою вивчення анамнезу та проведення шкірних алерготестів. Для проведення шкірних «прик» тестів використовували алергени виробництва «Імунолог», м Вінниця.

Всі отримані результати піддані статистичній обробці для параметричних і непараметричних критеріїв 3 використанням програми «Minitab 16». При аналізі перевірки розподілу на нормальність використовували тест Колмогорова-Смірнова, порівняння центральних тенденцій двох незалежних вибірок з використанням U-критерію
Манна-Уїтні і порівняння середніх двох незалежних вибірок за критерієм Стюдента. Кількісні змінні представлені у вигляді середніх значень і середньоквадратичних відхилень для параметричних методів і медіани з 1 і 3 квартилем для непараметричних. При множинному порівнянні показників антиендотоксинового імунітету використовували критерій Краскела-Уолліса.

Для всіх пацієнтів і волонтерів отримано добровільну письмову згоду на участь в науковому дослідженні, на який $€$ дозвіл комісії з біоетики.

\section{Результати досліджень та їх обговорення}

Залежно від ступеня постбронходилятаційного співвідношення ОФВ /ФЖєЛ було виявлено 151 пацієнта 3 фріксованою та 180 зі зворотною обструкцією. Основні клініко-анамнестичні параметри в досліджуваних субтипах представлені в таблиці 1.

Таблиця 1

Клініко-анамнестичні параметри у хворих на БА з фріксованою та зворотною обструкцією

\begin{tabular}{|c|c|c|c|}
\hline Параметр & $\begin{array}{l}\text { БА з фріксованою обструкцією, } \\
\text { n=151 }\end{array}$ & $\begin{array}{c}\text { БА зі зворотною обструкцією, } \\
\text { n=180 }\end{array}$ & $\mathrm{p}$ \\
\hline $\begin{array}{l}\text { Вік, роки } \\
(95 \% \text { ДІ) } \\
\end{array}$ & $\begin{array}{c}53,80 \\
(52,41-55,20) \\
\end{array}$ & $\begin{array}{c}50,66 \\
(48,93-52,40) \\
\end{array}$ & 0,006 \\
\hline Стать (Ч/Ж) & $47 / 104$ & $72 / 108$ & 0,094 \\
\hline $\begin{array}{l}\text { IMT, } \\
\text { (95 \% ДІ) }\end{array}$ & $\begin{array}{c}26,02 \\
(25,44-26,60)\end{array}$ & $\begin{array}{c}26,21 \\
(25,62-26,80)\end{array}$ & 0,646 \\
\hline $\begin{array}{l}\text { Вік початку БА, роки } \\
\text { (95 \% ДІ) }\end{array}$ & $\begin{array}{c}33,05 \\
(31,48-34,63)\end{array}$ & $\begin{array}{c}33,66 \\
(32,19-35,13)\end{array}$ & 0,578 \\
\hline $\begin{array}{l}\text { Тривалість БА, роки } \\
\text { (Ме, } 95 \% \text { ДІ) }\end{array}$ & $\begin{array}{c}20,00 \\
(18,00-24,00)\end{array}$ & $\begin{array}{c}14,00 \\
(12,00-6,63)\end{array}$ & 0,001 \\
\hline Пневмонія, n (\%) & $45(29,80 \%)$ & $52(28,89 \%)$ & 0,856 \\
\hline IXC, n (\%) & $49(32,45 \%)$ & $42(23,33 \%)$ & 0,065 \\
\hline ЕГ, n (\%) & $65(43,05 \%)$ & $59(32,78 \%)$ & 0,055 \\
\hline
\end{tabular}

Примітка: IXC - ішемічна хвороба серця, ЕГ - ессенціальна гіпертензія, р - достовірність відмінностей.

Вік пацієнтів з фріксованою обструкцією (табл. 1) був достовірно вище ( $p=0,006)$ порівняно з іншим субтипом. За такими параметрами як стать, IMT та вік початку симптомів БА достовірних відмінностей між досліджуваними групами встановлено не було. В свою чергу, тривалість БА у пацієнтів з фріксованою обструкцією була значно більшою $(p=0,001)$ порівняно зі зворотною. Кількість випадків пневмоній, IXC та ЕГ достовірно не відрізнялась у пацієнтів обох груп.

У пацієнтів з фріксованою обструкцією (табл. 2) кількість загострень та балів анкети ACQ були більше $(p<0,05)$ порівняно з іншою групою. Пацієнти зі зворотною обструкцією частіше приймали МЛ та низькі дози IKC, що достовірно їх відрізняло від субтипу 3 фріксованою обструкцією. В свою чергу, пацієнти 3 фріксованою обструкцією частіше приймали низькі або середні дози ІКС у комбінації з $\beta 2$-агоністами тривалої дії.

Отже, аналіз клінічних даних вказує на тяжчу форму захворювання у пацієнтів з фріксованою обструкцією, що може впливати на стан антиендотоксинового імунітету (табл. 3).

Рівні анти-ET-IgA та анти-ET-slgA (табл. 3) не відрізнялись від контролю. Концентрація анти-ЕТ-IgM була вище $(p<0,001)$ контролю в обох субтипах, хоча не відрізнялась між цими групами. Вміст анти-ET-IgG був вище $(p<0,001)$ контролю в обох групах, при цьому рівень цього імуноглобуліну був вище $(p<0,05)$ у пацієнтів з фріксованою обструкцією порівняно з іншим субтипом. Концентрація SCD14 в індукованому мокротинні була 
вище $(p<0,001)$ контролю в досліджуваних субтипах, хоча вміст цього медіатору в сироватці був вище $(p<0,05)$ контролю тільки для пацієнтів із зворотною обструкцією.

Використання медичних ресурсів та контролюючих препаратів у пацієнтів з фріксованою та зворотною обструкцією

\begin{tabular}{|c|c|c|c|}
\hline Параметр & $\begin{array}{c}\text { БА з фріксованою } \\
\text { обструкцією, n=151 }\end{array}$ & $\begin{array}{c}\text { БА зі зворотною } \\
\text { обструкцією, } n=180\end{array}$ & $\mathrm{p}$ \\
\hline \multicolumn{4}{|l|}{ Використання медичних ресурсів } \\
\hline Кількість загострень, Ме (95 \% ДІ) & $3(3-4)$ & $3(2-3)$ & 0,001 \\
\hline ACQ, бали, Me (95% ДІ) & $3,00(2,86-3,14)$ & $2,29(1,86-2,57)$ & $<0,001$ \\
\hline \multicolumn{4}{|l|}{ Тип контролюючих препаратів } \\
\hline МЛ (n, \%) & $4(2,65 \%)$ & $28(15,56 \%)$ & $<0,001$ \\
\hline Низькі дози IKC (n, \%) & $6(3,97 \%)$ & $57(31,67 \%)$ & $<0,001$ \\
\hline Середні дози IKC (n, \%) & $8(5,30 \%)$ & $19(10,56 \%)$ & 0,082 \\
\hline Низькі дози IKC +LABA (n, \%) & $37(24,50 \%)$ & $17(9,44 \%)$ & $<0,001$ \\
\hline Середні дози IKC +LABA (n, \%) & $66(43,71 \%)$ & $35(19,44 \%)$ & $<0,001$ \\
\hline Високі дози IKC+LABA (n, \%) & $9(5,96 \%)$ & $5(2,78 \%)$ & 0,152 \\
\hline Високі дози IKC+LABA +оральні стероїди (n, \%) & $21(13,91 \%)$ & $19(10,56 \%)$ & 0,352 \\
\hline
\end{tabular}

Примітки: МЛ - модифікатори лейкотриєнів, IKC - інгаляційні кортикостероїди, ACQ - Asthma Control Questioner, LABA - ß2-агоністи тривалої дії, ДІ - довірчий інтервал.

Таблиця 3

Показники антиендотоксинового імунітету у пацієнтів з фріксованою/зворотною обструкцією та здорових волонтерів

\begin{tabular}{|c|c|c|c|c|}
\hline Показник & Контроль (n=92) & $\begin{array}{c}\text { БА з фріксованою } \\
\text { обструкцією, n=151 }\end{array}$ & $\begin{array}{c}\text { БА зі зворотною } \\
\text { обструкцією, n=180 }\end{array}$ & p, т. K-Y \\
\hline Анти-ET-IgA (од.опт.щ.) & $\begin{array}{c}0,266 \\
(0,184-0,354)\end{array}$ & $\begin{array}{c}0,251 \\
(0,191-0,312)\end{array}$ & $\begin{array}{c}0,256 \\
(0,207-0,324)\end{array}$ & 0,628 \\
\hline Анти-ET-IgM (од.опт.щ.) & $\begin{array}{c}0,322 \\
(0,203-0,400)\end{array}$ & $\begin{array}{c}0,423^{a} \\
(0,335-0,491)\end{array}$ & $\begin{array}{c}0,391^{b} \\
(0,313-0,474)\end{array}$ & $<0,001$ \\
\hline Анти-ET-IgG (од.опт.щ.) & $\begin{array}{c}0,357 \\
(0,261-0,442)\end{array}$ & $\begin{array}{c}1,057^{a} \\
(0,817-1,377)\end{array}$ & $\begin{array}{c}0,965^{b, c} \\
(0,671-1,268)\end{array}$ & $<0,001$ \\
\hline Анти-ET-slgA (од.опт.щ.) & $\begin{array}{c}0,178 \\
(0,119-0,217)\end{array}$ & $\begin{array}{c}0,153 \\
(0,109-0,201)\end{array}$ & $\begin{array}{c}0,155 \\
(0,119-0,193)\end{array}$ & 0,0621 \\
\hline $\begin{array}{l}\text { sCD14, } \\
\text { сироватка (мкг/мл) }\end{array}$ & $\begin{array}{c}4,99 \\
(3,53-6,90)\end{array}$ & $\begin{array}{c}5,37 \\
(3,43-7,34)\end{array}$ & $\begin{array}{c}5,78^{\mathrm{b}} \\
(4,40-8,33)\end{array}$ & 0,0172 \\
\hline $\begin{array}{l}\text { sCD14, індуковане } \\
\text { мокротиння (нг/мл) }\end{array}$ & $\begin{array}{c}6,7 \\
(4,3-9,3)\end{array}$ & $\begin{array}{c}8,8^{\mathrm{a}} \\
(5,8-11,6)\end{array}$ & $\begin{array}{c}9,7^{\mathrm{b}} \\
(6,1-14,6)\end{array}$ & $<0,001$ \\
\hline
\end{tabular}

Примітка: a - достовірність відмінностей контролю та БА з фріксованою обструкцією, p <0,05; b - достовірність відмінностей контролю та БА зі зворотною обструкцією, p <0,05; c - достовірність відмінностей БА з фіксованою та зворотною обструкцією; т. К-У - тест Краскела-Уолліса.

Хронічне запалення у хворих з фріксованою обструкцією може мати системний характер. Для з'ясування відмінностей між фенотипами з фіксованою та зво- ротною обструкцією було проведено дослідження у 74 пацієнтів дорослого віку, які не курять (>45 років). Всі пацієнти були розділені на 2 групи: в 1-у групу увійшли 
34 особи, в яких спостерігалась фріксована обструкція (післябронходилятаційний ОФВ $1 \leq 70 \%$, ОФВ 1 /ФЖЄЛ <норми); 2-у групу склали 40 пацієнтів 3 нормальною функцією легень. Результати дослідження показали, що для пацієнтів з фіксованою обструкцією порівняно 3 контрольною групою було характерне підвищення рівня системного запалення (зростання концентрації видихуваного оксиду азоту), порушення гомеостазу глюкози та центральне ожиріння. Для фріксованої обструкції також були характерними більша тривалість хвороби та часті респіраторні інфекції в дитинстві [10].

Результати нашого дослідження показали, що у пацієнтів з фріксованою обструкцією спостерігається підвищена активація специфічної і адаптивної (висока концентрація анти-ET-IgG) та анергія системної і неспецифічної (нормальне значення сироваткового sCD14) ланки імунної відповіді на лПС.

\section{Висновки}

У пацієнтів з фріксованою обструкцією спостерігається підвищена активація специфічної і адаптивної та анергія системної і неспецифрічної ланки імунної відповіді на ендотоксин.

\section{Література}

1. Fixed airways obstruction among patients with severe asthma: findings from the Singapore general hospital - severe asthma phenotype study / [A.C. Yii, G.L. Tan, K.L. Tan et al.] // BMC pulmonary medicine. - 2014. - Vol. 14, N 1. - P. 191.

2. Fixed airflow obstruction due to asthma or chronic obstructive pulmonary disease: 5-year follow-up / [M. Contoli, S. Baraldo, B. Marku et al.] // J. Allergy Clin. Immunol. - 2010. - Vol. 125, N 4. - P. 830-837.

3. Lambrecht B.N. The immunology of asthma / B.N. Lambrecht, H. Hammad // Nature Immunology. - 2015. - Vol. 16, N 1. - P. 45-56.

4. Simpson A. The role of lipopolysaccharide in the development of atopy in humans / A. Simpson, F.D. Martinez // Clin. Exper. Allergy. - 2010. - Vol. 40, N 2. - P. 209-223.

5. Biswas S.K. Endotoxin tolerance: new mechanisms, molecules and clinical significance / S.K. Biswas, E. Lopez-Collazo // Trends in immunology. - 2009. - Vol. 30, N 10. - P. 475-487.

6. O-antigen delays lipopolysaccharide recognition and impairs antibacterial host defense in murine intestinal epithelial cells / [C.U. Duerr, S.F. Zenk, C. Chassin et al.] // PLoS Pathog. - 2009. - Vol. 5, N 9. - P. e1000567.
7. Czerkies M. Toll-like receptors and their contribution to innate immunity: focus on TLR4 activation by lipopolysaccharide / M. Czerkies, K. Kwiatkowska // Advances in Cell Biology. - 2014. - Vol. 4, N 1. - P. 1-23.

8. Патент 70193 А Україна МКІ 7 А61К31/01 Спосіб визначення антитіл до ліпополісахаридів грамнегативних бактерій / А.І. Гордієнко, В.О. Білоглазов. - Заявл. 29.12.2003; Опубл. 15.09.2004, Бюл. № 9.

9. Гордиенко А.И. Использование твердосразного иммуносрерментного анализа для определения общего и антиэндотоксинового секреторного IgA человека / А.И. Гордиенко // Таврический мед.биол. вестник. - 2009. - Т. 12, № 3. - Р. 82-89.

10. Fixed airflow obstruction among nonsmokers with asthma: a case-comparison study / [P. Sexton, P. Black, L. Wu et al.] // J. Asthma. - 2013. - Vol. 50, N 6. - P. 606-612.

\section{STATE OF SPECIFIC IMMUNITY TO ENDOTOXIN FOR PATIENTS WITH BRONCHIAL ASTHMA WITH THE FIXED/ CIRCULATING OBSTRUCTION}

Yu.A. Bisyuk

SUMMARY. The study included 331 patients with asthma. Depending on the degree of post-bronhodilyatatsionoho ratio of FEV1/FVC there were identified 151 patients with fixed and 180 with reversible obstruction. Levels of anti-endotoxin antibodies of A, M, G classes and SCD14 were determined by ELISA. The results showed that the level of ant-endotoxin IgG was significantly higher $(P<0.001)$ in both control groups, while the level of this immunoglobulin was significantly higher $(P<0.05)$ in patients with fixed obstruction compared to reversible one. A concentration of SCD14 in induced sputum was significantly higher $(P<0.001)$ compare to control in both study groups, although the level of this mediator in serum was significantly higher $(P<0.05)$ only in patients with reversible obstruction.

Key words: bronchial asthma, endotoxin, immunity.

Отримано 25.11.2015 р. 